\title{
EXPERTISE, INDEPENDENCE AND PROFESSIONAL SKILLS OF INTERNAL AUDITORS IN PREVENTING FRAUD ON E-COMMERCE TRANSACTIONS (A CASE STUDY AT PT KERETA API INDONESIA)
}

\author{
Arsy Eza Febie Romadhina \\ STIE (School of Business and Banking) Perbanas Surabaya \\ Email: arsy.eza.04@gmail.com
}

\author{
ARTICLE INFORMATION \\ Article history: \\ Received April08, 2016 \\ Revised May26, 2016 \\ Accepted June28, 2016

\section{JEL Classifications} \\ M42
}

\section{Key Words:}

Internal Auditor,

Fraud,

E-Commerce

DOI:

10.21532/apfj.001.16.01.02.25

\begin{abstract}
Nowadays, the development of information technology has given significant impact on various activities. Easy facilities provided by information technology enable the society, especially costumers, to make transactions at their workplace or home. Such demands make producers and companies feel the need to apply e-commerce their business. This research aims to give information about the expertise, independence, and professional skill of the internal auditors in preventing fraud on e-commerce transactions. This research applies Miles and Huberman model with three activities in the data analysis, such as: data reduction, data model, and conclusion withdrawal. This research uses qualitative research with a case study at PT KeretaApi Indonesia (Persero). The result obtained from this research shows that the audit process of e-commerce at PT KeretaApi Indonesia (Persero) is entirely conducted by the Internal Auditors in IT Unit, because IT Unit has its own Team of Auditors outside the SPI Unit (Internal Auditor Unit) of PT KeretaApi Indonesia (Persero).
\end{abstract}

\section{INTRODUCTION}

The development of information technology has given significant impact on various activities. Facilities provided by information technology enable the community, especially customers, to make transactions at their workplace or home easily and comfortably. The increasing public demand for easy facilities has prompted manufacturers and companies to apply e-commerce to support their business. In addition to providing convenience to the public and consumers, e-commerce can also save costs to be borne by producers 
or companies. E-commerce can be defined as the ability to conduct transactions between two or more parties using computers connected to network. This network can be built using phone lines, cable TV channels, land-radio, or satellite radio (Kalakota, 1996 in SaringSuhendro, 2007). E-commerce covers Electronic Data Interchange (EDI), Electronic Funds Transfer (EFT), Automated Teller Machines (ATMs), and some businesses done using the internet (SaringSuhendro, 2007).

E-commerce business has an impact on business management in general, because business transactions on e-commerce are conducted electronically. In manual business, accounting information system is a closed company's internal system which cannot be accessed by customers. But in e-commerce business, customers can make reservations and even see the inventory of the company easily (VirtaniaShieldsaWijono 2012). Based on the description above, the e-commerce transactions conducted by the company greatly require the role of internal auditors to assist management in conducting internal control. The duties of internal auditors are to conduct an audit and to provide value and to give recommendation related to the audit findings. TumpalManik (2012) defines an audit as a systematic process to obtain and objectively evaluate the evidence relating to the assessment of the various economic activities and events in order to ensure the level of conformity among the assessments, to establish criteria, and to submit the results to the users concerned.
An auditor is required to develop his software audit tools enabling to perform the audit with the available software to implement the control test on the e-commerce environment, or better known as Continuous Audit Tools and Techniques (CATTs). CATTs are tools and techniques which are used by the auditor to determine the risk, evaluate the internal control and performance electronically from various audit procedures, extract the data, download the information for a review of the analysis, footing ledger, deposit the calculation, select the samples for control testing and substantive testing, identify the exceptions and unusual transactions, and confirm the performance.

The impact arising from the application of e-commerce is that perpetrators always search for loopholes to commit fraud, so the management and internal auditors should work hard to take precautions before the fraud occurs.

This research is conducted at PT. KeretaApi Indonesia (Persero) for this company is one of the companies that implement e-commerce transactions. PT. KeretaApi Indonesia (Persero) has implemented e-commerce transactions since 2011. The implementation of e-commerce at PT. KeretaApi Indonesia (Persero) is using B2B (business to business) system and B2C (business to customer) system. B2B Partners consist of payment point, supermarket / minimarket, web, and banking institutions with a total of 34, while B2C Partners are agents in Java and Sumatra with a total of 500 agents. The development of technological innovations for the application of e-commerce business conducted by PT. KeretaApi Indonesia 
(Persero) started in 2011 and has been growing until this day.

With the implementation of e-commerce, PT KeretaApi Indonesia (Persero) experiences a lot of progress, for example, today many stations look clean and tidy, no more passengers queue up for hours at ticket booths, and so on. E-commerce also makes the stowaway increasingly difficult to break in because the boarding system at the entrance requires passengers to show original identity card that must be the same as the identity indicated on the ticket.

The formulation of the problem to be addressed is "how can the expertise, independence and professional skills of internal auditors prevent fraud on e-commerce transactions? The results of this research are expected to provide information on the expertise, independence and professional skills that should be owned by the internal auditors in preventing fraud on e-commerce transactions.

\section{THEORETICAL FRAMEWORK}

\section{Internal Audit}

Auditing is a systematic process for obtaining and evaluating evidence objectively related to the assertion of economic actions and events to determine the level of compliance between the assertion and the established criteria, and communicating the results to the parties concerned. (Al. HaryonoJusup, 2014: $10)$.

Internal audit is a systematic process for obtaining and evaluating assertion of economic actions and events objectively. (Sawyer et al, 2003: 8 in WuryanAndayani, 2008: 3). Institute of Internal Auditors (IIA) issued Standards for the Professional Practice of Internal Auditing (SPPIA) defining internal audit as an independent appraisal function within the company to examine and evaluate the activities of the company. Internal auditor is an auditor who works for an entity (company) and therefore his status is as an employee of the entity. (Al. HaryonoJusup, 2014: 18).

Sawyer et al, (2003: 35-38) in WuryanAndayani (2008: 4-5) says that in all situations, the internal audit department assists manager in a variety of ways, such as monitoring the activities that cannot be monitored by the top management, identifying and minimizing risks, validating reports to senior management, protecting the management in technical area, assisting in the decision making process, analyzing not only the past but also the future, and assisting manager to manage the company related to planning, organizing, directing, and controlling.

If the internal auditor finds an indication of fraud in the organization, the internal auditor must report it to the relevant parties within the organization, such as audit committee. The internal auditor can provide recommendations for the investigation required to investigate the fraud (Fitrawansyah, 2014: 16-17).

Internal audit in public sector can be carried out by the inspectorate in each department and by the Finance and Development Supervisory Agency (BPKP) based on request from the government. The technical and audit process 
is not much different from what is done in the private sector.

\section{Auditing Standards}

Auditing standards are general guidelines to assist the auditors in fulfilling their professional responsibilities in the audit of financial statement history. Those standards include professional quality considerations such as the requirements of competence and independence, reporting, and evidence. (Al. HaryonoJusup, 2014: 58).

The purpose of the standards is to explain the basic principles that reflect the basic practice of internal auditing, to provide a framework, to set the basis of performance measurement, and to foster organizational and operational processes.

Internal auditing standards were first issued in June 1978 by the Institute of Internal Auditors (IIA) at an international conference in San Francisco. There are five common standards of internal auditor, namely: independence, professional expertise, scope of work, implementation of audit work, and management of internal audit department.

Attributestandards discuss thecharacteristics and the individuals who perform internal audit services, comprising: independence and objectivity, expertise and proficiency in the use of professional expertise, and quality assurance and compliance. Performance standards spell out the nature of internal audit services and provide quality criteria for measuring the implementation of audit services, comprising: managing the internal audit activity, the nature of work, planning and implementation of the assignment, communicating the results, and monitoring the progress. Implementation standards are to implement the attribute standards and performance standards on certain types of services.

\section{Expertise and Training of Internal Auditor}

An auditor shall act as an expert in the fields of accounting and auditing, the achievement of these skills starts from formal education which is later expanded through experience and auditing practices. In addition, an auditor must undergo sufficient technical training. Such training must adequately cover technical aspects as well as formal education (Source: Public Accountants Professional Standards 2011).

An internal auditor is required to have knowledge, skills, and competence that can be used in the audit process as an individual responsibility. The head of internal audit has an obligation to refuse to assign the member of internal auditor who does not have adequate knowledge, expertise and competence. Expertise and training, in this study, are assessed based on the compliance with the Performance Standards, understanding the intricacies of business activities, identification of fraud, how the auditor gets the knowledge and wealth of experience of the auditor.

\section{Independence of Internal Auditor}

An auditor must be independent, which means that the auditor is not easily influenced, because the auditor carries out his duties for the public interest. An auditor must be free of any 
liability towards the client and has no interest with the client (the management of the company or the owner of the company) (Source: Public Accountants Professional Standards 2011).

The responsibility as an internal auditor in the company makes the internal auditor sit on the function that has unrestricted access to management and supervisory board. Independence, in this study, is assessed based on the openness of the auditor in revealing fraud, close relationship with related divisions, how the auditor maintains the independence, and other activities outside the company.

\section{Professional Skills of Internal Auditor}

The use of careful and accurate professional skills is related to what is done and the perfection of the work of an auditor. This requires an auditor to carry out professional skepticism and obtain adequate assurance to the financial statements that are free of material misstatement caused by either error or fraud. Professional skepticism is an attitude that includes a questioning mind and critical evaluation of the audit evidence (Source: Public Accountants Professional Standards 2011).

Professional skills, in this study, are assessed based on the level of ability and confidence of an auditor in performing the audit process. The auditor's ability is measured by the ability to analyze the audit documents, the ability to determine the risk, as well as other abilities that should be owned by the auditor to carry out his duties and responsibilities. The confidence of auditor is measured by how the auditor believes the opinion given and believes whether the evidence obtained is reliable enough.

\section{Definition and Types of Fraud}

According to Black Law Dictionary in Fitrawansyah (2014: 8), fraud is an intentional misstatement to the truth, or concealment of material facts that may influence other people to commit an adverse act or acts. It is usually an error, but in some cases (particularly committed intentionally), it is likely a crime or misstatement that is done carelessly, recklessly, or unbelievably and may affect or cause others to commit adverse act or acts. Fraud can also be defined as a loss arising as a result of misstatement, concealment of material facts, or careless or reckless statements that influence others to commit adverse act or acts.

According to the Association of Certified Fraud Examiners (ACFE), internal fraud is classified into three (3) types: fraud in assets, fraud in financial statements, and corruption (Fitrawansyah, 2014: 9-10).

\section{E-commerce}

E-commerce is a digital environment applied by organizations and individuals that enables commercial transactions to occur. The transactions may occur through the internet and the web. These commercial transactions involve exchange of value (money) in return of goods or services that cross the boundaries of the organizations or individuals.

Kenneth C. Laudon (2007: 63) wrote in his book, there are three main categories of e-commerce: (1) E-commerce business to consumer (B2C) which involves the sale of products and services at retail to individual buyers; (2) E-commerce business to business 
(B2B) which involves the sale of products and services inter-companies; (3) E-commerce consumer to consumer $(\mathrm{C} 2 \mathrm{C})$ which involves consumers who sell directly to consumers.

The framework in this study is illustrated as follows:

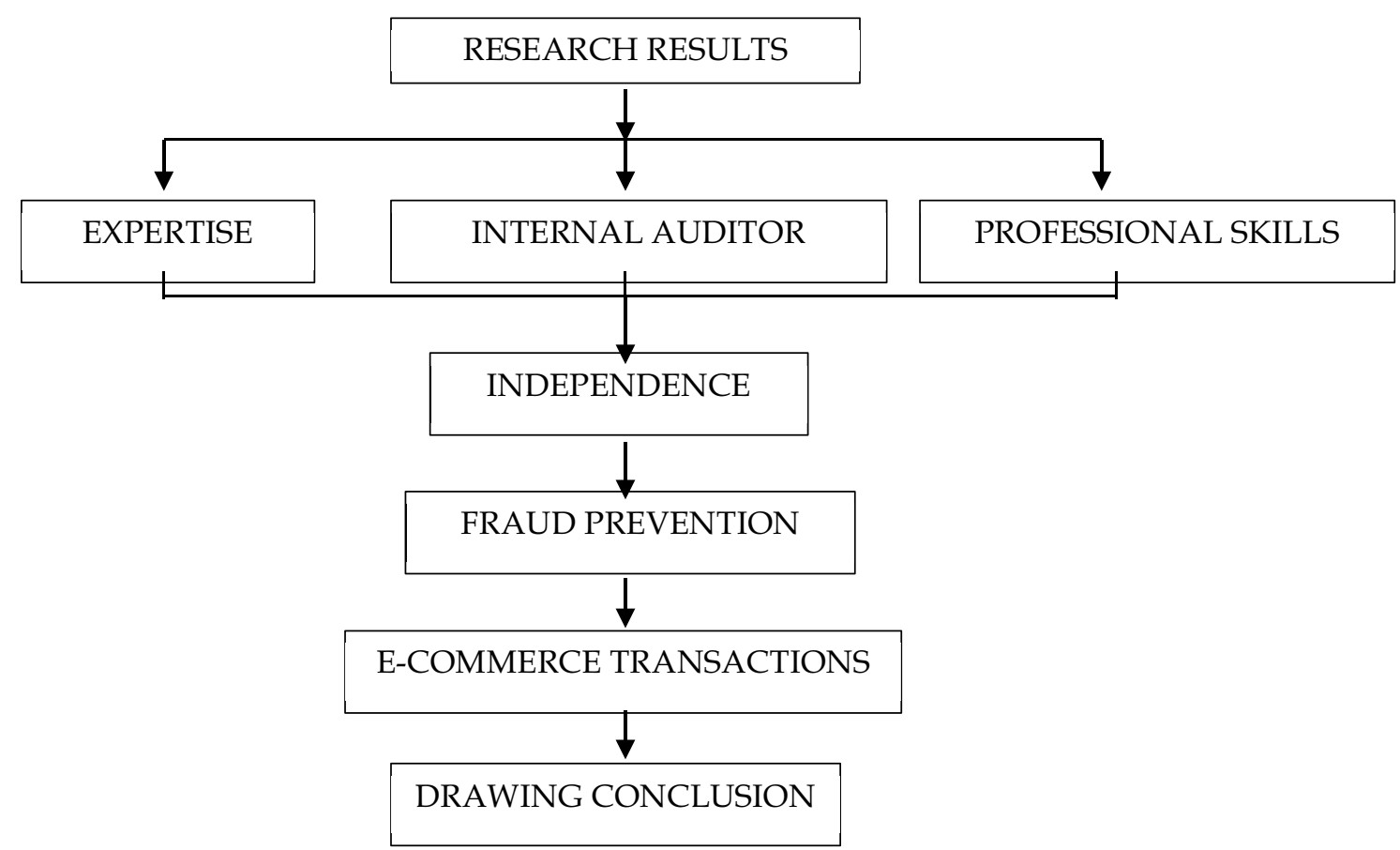

Figure 1

Framework

\section{RESEARCH METHOD}

\section{Research design}

This study is a qualitative study using Miles and Huberman model with three kinds of activities in analyzing the data, namely data reduction, data models, and conclusion withdrawal. Data reduction is the process of selecting, focusing, abstracting, and transforming the data in written records. Data model is a collection of information that allows the withdrawal of conclusion. Conclusion withdrawal is to give the meaning of the data collected.

The characteristic of qualitative research used is naturalistic characteristic, a research with actual background as a direct data source and the researcher as a key instrument, and using a case study at PT. KeretaApi Indonesia (Persero). A case study is a type of research that tries to express the meaning, investigate the process and gain the insight and in-depth understanding of a subject. The researcher will conduct closed and open interviews with internal auditors and management of PT. KeretaApi Indonesia (Persero) related to expertise, independence and professional skill in preventing fraud on e-commerce transactions applied at PT. KeretaApi Indonesia (Persero) and then analyze the results of these interviews and provide conclusions at the end of the study. 
Type of interview used in this study is therapy interview. Therapy interview is used to identify and eliminate factors that cause the problem and increase the informant's confidence in doing his job. The types of questions presented in this study are exploratory and explanatory case studies. Exploratory case study means that the questions refer to the question of "what", while the type of explanatory means that the questions refer to the question of "how" and "why".

\section{Scope of the Study}

The scope of the study is at PT. KeretaApi Indonesia (Persero) by conducting interview with the internal auditors of PT KeretaApi Indonesia (Persero), or commonly called as Internal Audit Unit (SatuanPengawas Intern / SPI) and the Unit of Marketing and Sales of Passenger Transport. The interview relates to e-commerce transactions conducted by PT. KeretaApi Indonesia (Persero), assessments of the internal auditor, as well as the prevention of fraud.

\section{Respondent and Informant}

The criteria for the internal auditors who will be the respondents are determined based on the length of work of the respondents at PT. KeretaApi Indonesia (Persero) and the auditors who have ever checked or carried out an audit in the area of e-commerce. The criteria for the management who will be the respondents are determined based on their department or division, preferably the department or division directly involved in dealing with e-commerce, namely the Unit of Marketing and Sales of Passenger Transport.

\section{Analysis Techniques}

The data analysis technique used is Miles and Huberman model with the following steps: (1) Conducting interview with internal auditors. (2) Gathering data on e-commerce at PT. KeretaApi Indonesia (Persero) by conducting interviews with marketing and sales unit of passenger transportation. (3) Analyzing the structure or parties related to e-commerce transactions. (4) Analyzing the control systems and procedures on e-commerce transactions. (5) Analyzing the threat and the precautions taken on e-commerce system. (6) Analyzing the advantages and disadvantages of e-commerce system and handling method. (7) Analyzing the results of interviews with the internal auditors related to expertise, independence and professional skills in preventing fraud on e-commerce transactions. (8) Drawing conclusions as to how the expertise, independence and professional skills of internal auditors can prevent fraud on e-commerce transactions. (9) Providing suggestion and recommendations.

\section{DATA ANALYSIS AND DISCUSSION} Internal Audit Unit (SPI) serves as the Internal Auditor of PT KeretaApi Indonesia (Persero)

The Internal Audit of PT KeretaApi Indonesia, which is carried out by the Internal Audit Unit (SPI), is headed by a Chief of SPI, having the same level as Executive Vice President, who directly responsible to the President Director. The appointment and dismissal are conducted through the approval process of the Board of Commissioners. The Internal Audit Unit (SPI) of PT KeretaApi 
Indonesia (Persero) is working in accordance with the Annual Audit Work Program (PKAT) drawn up in the previous half a year systematically and effectively.

The duties and responsibilities of the Internal Audit Unit (SPI) are made based on the Internal Audit Charter guidelines that have been established by Decree of Board of Directors No. KEP.U / OT.104 / VII / 1 / KA-2012 with the approval of the Board of Commissioners on July 19, 2012. The Internal Audit Charter was drawn up based on the guidelines of the Implementation Standards of the Function of Internal Audit Unit (SPF SPI) and the Code of Ethics of Internal Control of SOEs (BUMN) that have been set at SPI Communication Forum and the International Standars for Professional Practice of Internal Auditing established by the Institute of Internal Auditors (IIA).

Evaluation of internal control is conducted by Public Accounting Firm (KAP) by distributing questionnaires to officials in the central and regional offices of PT KeretaApi Indonesia (Persero). Evaluation of information technology involves SPI, Risk Management, and Information Systems. Evaluation of internal control system is also conducted by the Internal Audit Unit (SPI) through auditing.

\section{History and Development of E-Commerce at PT KeretaApi Indonesia (Persero)}

The implementation of e-commerce started in 2011 by implementing rail ticket system, aticket booking through partners in cooperation with PT KeretaApi Indonesia (Persero). Prior to the implementation of e-commerce, prospective passengers should come directly to the station to book tickets. Currently, PT KeretaApi Indonesia (Persero) has collaborated with more than $34 \mathrm{~B} 2 \mathrm{~B}$ partners and $500 \mathrm{~B} 2 \mathrm{C}$ agents throughout Java and Sumatra.

Ticket sales channels of PT KeretaApi Indonesia (Persero) consist of: (1) internal sales channel, which is directly managed by $\mathrm{PT}$ KeretaApi Indonesia (Persero) such as stations, web, and mobile, and (2) external sales channel, which is managed by Partners. The Partners in PT KeretaApi Indonesia (Persero) consist of B2B and B2C. There is no limitation on selling systems on B2B partners. But on B2C partners, namely agent, PT KeretaApi Indonesia (Persero) provides limitation system, such as on the tickets sold.

\section{Background of the Application of E-commerce at PT KeretaApi Indonesia (Persero)}

The purpose of the application of e-commerce at PT KeretaApi Indonesia (Persero) is that the prospective passengers do not have to come to the station to queue for tickets and the station becomes clean and conducive. With the application of e-commerce, it is expected that the prospective passengers go to the station just for printing the tickets at the self-service ticket machine before the departure time, while the station counter will only be used for travel transactions of close distance train or commuter train.

Reduced activities in the station is expected to minimize the costs incurred by PT KeretaApi Indonesia (Persero), such as cleaning costs, security costs, and counter guard costs 


\section{E-commerce at PT KeretaApi Indonesia (Persero)}

Types of e-commerce provided by PT KeretaApi Indonesia (Persero) are:

(1) Internet Reservation, in which tickets booking through internet can be done by opening the official website www. tiket.kereta-api.co.id and the prospective passengers can book tickets from 90 days to 2 days before the departure. The prospective passengers are asked to fill in personal data in accordance with the valid identity card, and to select the station of departure and destination, departure date, and number of passengers. The prospective passengers can then make payments via a payment channel.

(2) Rail Card and Rail Box, Rail Card is a prepaid card which is used to purchase tickets in lieu of cash that can also function as a train membership card and can also be used to shop at merchants that put the logo BNI Prepaid. Rail Card can be purchased at BNI branch offices and Customer Service at the station for IDR 20,000 and can be recharged up to IDR 1,000,000. Rail Box is a machine, placed in stations, malls, and other places that have been determined, which is used to perform ticket sales transactions using Rail Card. Rail Box to work for 24 hours. How to perform a transaction is by attaching the Rail card to the Rail Box machine and then the prospective passenger is asked to fill in data and choose the train as well as the schedule of departure time, then the receipt of booking code will come out of the Rail
Box and the receipt can be exchanged for ticket at the station counter.

(3) Contact center 121 is a ticket reservation by calling 121 (PSTN) or 021-121 (GSM) to make a reservation 90 days to 5 hours before the departure. Then the prospective passenger can make payment through payment channels. It is the same as when making a booking using the internet. The payment is made up to three hours after getting a booking code and is considered void if it does not make any payment within that period. Proof of payment is then exchanged for tickets at the nearest online station.

(4) Rail Agent is a business entity or a legal entity representing PT KeretaApi Indonesia (Persero) to do marketing, promotion and ticket reservations. These agents spread across Java - Sumatra, among others in Greater Jakarta, Bandung, Cirebon, Semarang, Purwokerto, Yogyakarta, Madiun, Surabaya, Sidoarjo, Tuban, Jember, Medan, Palembang, and Bandar Lampung.

(5) Mobile Ticketing Online, the service is still available only in Operational Area (Daop) 1 Jakarta, Daop 3 Cirebon, and Daop 5 Purwokerto. This service also provides delivery order service for the area around Purwokerto. To purchase tickets for a minimum of ten tickets may call 02817912699.

(6) Online Station, the service is in the form of Self-Service Ticket Machine scattered at several stations, and the prospective passengers can print the ticket by 
themselves, without queuing at the counter, by entering the booking code.

(7) Drive THRU, the service is available at the stations of Gambir, Cirebon, and Semarang Tawang, and will soon follow in other cities. The service operational hours start from 7 a.m. to 7 p.m.

\section{Parties Related to E-commerce Transactions}

These parties include: agent, counter, payment point, minimarket (Indomaret, Alfamart, Alfamidi, etc.), web (tiket.kereta-api. co.id), mobile application (KAI Access), and banking institutions.

\section{Control Systems and Procedures on E-commerce Transactions}

E-commerce system of PT KeretaApi Indonesia (Persero) is built by the IT department. The task of the IT department is to prepare and build the system of e-commerce application. When the system is ready to be used, it will be submitted to the commercial department as the user. If there is a fault or damage to the system, the commercial department will report to the IT department for further action.

Control procedures of e-commerce at PT KeretaApi Indonesia (Persero) are carried out entirely by the commercial department, at the Unit of Ticket Sales of Passenger Transport, so that the Partners who have cooperated with PT KeretaApi Indonesia (Persero) as B2B (Business to Business) and B2C (Business to Customer) must be registered in advance. PT KeretaApi Indonesia (Persero) can stop the system at one of its partners if deemed any irregularities on the partner, such as unrealistic sales.

\section{Advantages and Disadvantages of E-commerce System and Handling Method}

The advantages of e-commerce system applied at PT KeretaApi Indonesia (Persero) are: Cost Efficiency, people no longer need to queue up to buy tickets so there is no need to open many ticket counters, and the station become cleaner and safer. These can reduce the cost of human resources, such as ticket counter guards, securities, and janitorial services, and minimize fraud, in which errors occurring on the partners are the sole responsibility of the partners. The data existing on partners is a system centralized to PT KeretaApi Indonesia (Persero) so that the partners must be registered in advance to be able to access the system. The system is also fully controlled by PT KeretaApi Indonesia (Persero). The existence of automatic delay system can reduce or eliminate the number of brokers.

The disadvantage of e-commerce system applied at PT KeretaApi Indonesia (Persero) is the lack of direct supervision, for example, when the prospective passengers doing transactions at one of the Partners (Indomaret / alfamart / etc), PT KeretaApi Indonesia (Persero) does not know anything about what going on during the transaction process. Another example is that the brokers can steal tickets from the SelfService Ticket Machines because the machines are not always monitored 24 hours by security officers. To anticipate this condition, PT KeretaApi Indonesia (Persero) installs CCTV on each Self-Service Ticket Machine and also gives a seal on the ticket printer. 


\section{Possible Fraud Committed by Internal Party of PT KeretaApi Indonesia (Persero)}

Fraud can be committed by either external or internal party. Fraud tends to be done for personal benefit and harm to the company. Here are the possible frauds committed by internal parties: (1) Damaging e-commerce system, this may be done by internal parties because they know more how the system is made and how the system works. (2) Making fictitious transaction records related to e-commerce.

\section{Possible Threats to the E-Commerce System of PT KeretaApi Indonesia (Persero)}

Hacker, since the operation of the e-commerce system in PT KeretaApi Indonesia (Persero), the system has never been tampered by hackers. But once, the system slowed down due to the increasing number of visitors to the online ticket booking services and the robots created by the perpetrators of the fraud to make the system down so that many train seats were empty and other prospective passengers could not make reservation.

Error System on the Partner (Mitra), all the errors caused by the Partner are the partner's liability, for example, a prospective passenger is booking ticket through a Partner, but the system declares fail, while the system in PT KeretaApi Indonesia (Persero) declares successful, then the prospective passenger still has to pay the amount of the order through the Partner. The anticipation conducted by PT KeretaApi Indonesia (Persero) to control over the Partner is by closing the Partner access to the system. This is done if the Partner is having problems on the systems owned by the partner and unrealistic purchase within a certain time limit.

\section{ANALYSIS AND DISCUSSION \\ Expertise of Internal Auditor}

Each member of Internal Audit Unit (SPI) of PT KeretaApi Indonesia (Persero), from junior auditor to the Head of SPI is required to understand the applicable Internal Audit Standards. All audit activities refer to these standards and the Head of SPI as the party who is responsible for assessing the implementation of the audit.

Identifying the presence or absence of fraud is the standard of internal audit, and detecting fraud is part of the expertise of the auditor, but not to disclose such fraud because there are several types of fraud that can and cannot be disclosed. It can happen because of the limited evidence or supporting documents to conduct an analysis of the fraud. The expertise of the internal auditor of PT KeretaApi Indonesia (Persero) can be developed through sustainable education, training, seminars, knowledge sharing intern and certification.

The expertise of the internal auditor in understanding e-commerce business is conducted through exposure, analysis, and complaints to the Internal Audit Unit (SP or by performing a preliminary audit. Exposure is usually performed by each unit in order to inform the activities of the unit so that the SPI understands the general activity of the unit. Analysis is conducted to understand more deeply. Complaint is usually carried out by 
related units, in this case the Commercial Unit and IT Unit, if it is perceived necessary for the SPI to conduct investigation to the Units.

The more experience gained, the more expertise the auditor in analyzing documents, analyzing the behavior, conducting interview techniques, as well as other supporting skills to detect fraud.

Expertise is the most important factor to assist the auditor in preventing fraud. The more knowledge gained from formal and informal education, the more expertise the auditor in performing the audit process. Added with the experience acquired, the internal auditor will be more confident in determining the risk factors and analyzing the existing risks.

\section{Independence of Internal Auditor}

An internal auditor should have professionalism, integrity, and independence in accordance with the established standards and should avoid things that could cause a conflict of interest with the auditee.

At PT Kereta Api Indonesia (Persero), in maintaining the independence of internal auditor, a new member of SPI is not allowed to conduct an audit inhis unit of origin for one year. An intimate relationship with co-workers between the units is required to perform consulting function of SPI, as long as this intimate relationship does not pose a conflict of interest and independence as a member of SPI. SPI members must remain independent in accordance with the standards.

The Internal Audit Unit (SPI) members are not allowed to work for other agencies in accordance with the provisions of employment, but are allowed to be a speaker or a resource person in an activity or event.

SPI will report all audit the results to the managing director based on the adequate and relevant evidence during the audit process.

Independence is required by the internal auditor in order to protect the internal auditor from any conflict of interest that could affect the performance of auditor.

\section{Professional Skills of Internal Auditor}

In carrying out the duties and obligations as an internal auditor, SPI is required to use all the knowledge, skills, and experience in performing audit process. An internal auditor must also have a high self confidence in carrying out the audit process in accordance with the applicable standards.

SPI members must have professional skills in examining the finance department but do not give opinion on the financial statement because it has been inspected by Public Accounting Firm (KAP) and the Supreme Audit Board of the Republic of Indonesia (BPK RI) and the Finance and Development Supervisory Agency (BPKP),as external auditors, that perform an audit at PT KeretaApi Indonesia (Persero).

Skepticism, as an internal auditor, is required to believe in the audit evidence obtained, in which the auditor is required to perform critical analysis and evaluation on the evidence and has a high curiosity with the evidence obtained as long as the evidence is still considered less sufficient, less relevant and less reliable. 
The SPI of PT KeretaApi Indonesia (Persero) plans and decides the outcome of the audit based on the facts found during the inspection process through discussion and confirmation with the relevant parties, and then reports the results to the managing director and the Unit.

Professional skills are required in believing the evidence obtained during the audit process and also in determining the opinion of the findings. From the findings, it is expected to be able to correct any errors before the audit is carried out.

\section{CONCLUSION, LIMITATION, AND SUGGESTION}

Based on the results of interviews, it can be concluded that the audit process on e-commerce at PT KeretaApi Indonesia (Persero) is fully carried out by the internal auditor in the IT Unit, because the IT Unit has its own team of auditors outside the Internal Audit Unit (SPI) of PT KeretaApi Indonesia (Persero). Since IT Unit requires immediate handling, it is necessary to own a team of auditors. SPI will ask for clarification related to e-commerce to the IT Unit, as the system builder, and also to the Commercial Unit to know the work process of the e-commerce. SPI will utilize information from IT auditors related to the characteristics of fraud that may occur in e-commerce transactions.

From the initial implementation of e-commerce to the present time, the system owned by PT KeretaApi Indonesia (Persero) can be said safe from the possibility of fraud.
The weaknesses and threats can be addressed and prevented by PT KeretaApi Indonesia (Persero).

Based on the research that has been done, it can be concluded that the expertise, independence and professional skills of internal auditors are essential in carrying out their duties and obligations. However, the Internal Audit Unit (SPI), as the internal auditor of PT KeretaApi Indonesia (Persero), has not directly addressed the e-commerce due to the existence of auditors in the IT Unit.

The limitation of this study is that the researcher could not reveal how the internal auditor prevents fraud directly on e-commerce transactions because, in PT KeretaApi Indonesia (Persero), IT Unit has its own auditors outside the Internal Auditor Unit (SPI), so the possibility of fraud can be prevented early by the IT unit.

The suggestions that can be used by PT KeretaApi Indonesia (Persero) are if the duties and obligations of the auditors of IT Unit are not different from those of SPI, conducting evaluation and consulting, it would be better to include the auditors of IT Unit as part of the Internal Audit Unit (SPI) so that the duties and responsibilities of the internal auditors can be centralized. But, in the division of the scope of work, SPI can be subdivided so that the focus of audit is in accordance with the need, such as IT audit, financial audit and other audits.

There are some suggestions that can be used by further researchers who use similar topics: (1) further researches can be done in companies 
with different areas that apply e-commerce, (2) further researches can use two sources of primary data, conducting interviews with the company party and providing questionnaires to service users, in order to know the difficulties or fraud perceived by consumers

\section{REFERENCES}

Al. HaryonoJusup. 2014. Auditing (Pengauditan Berbasis ISA).Edisi II. Yogyakarta :Universitas Gadjah Mada.

Daniel, Setyo Budi. Personal Interview di Kantor Pusat PT Kereta Api Indonesia (Persero). Bandung. 29 Desember 2015.

Emzir. 2012. Analisis Data :Metodologi Penelitian Kualitatif. Jakarta : Rajawali Pers.

Fitrawansyah. 2014. Fraud \& Auditing. Mitra Wacana Media. Jakarta

Institut Akuntan Publik Indonesia (IAPI). 2011. Standar Profesional Akuntan Publik, Salemba Empat, Jakarta.

Jodi. Personal Interview di Kantor Pusat PT Kereta Api Indonesia (Persero). Bandung. 6 Januari 2016.

Laudon, C. Kenneth \& Jane P. Laudon. 2008. Sistem Informasi Manajemen :Mengelola Perusahaan Digital.Edisi 10. Salemba Empat, Jakarta

Manik, T., \& Si, M. Analisis Penerapan Sistem Informasi Akuntansi Dan Audit Electronic Data Processing Melalui Electronic Commerce Dalam Mengendalikan Transaksi Pembayaran On-Line.
Nugroho, M. A. 2011. Audit Lingkungan Ti: Perspektif Dan Dampak Pada Proses Auditing Secara Komprehensif. Jurnal Pendidikan Akuntansi Indonesia, 9(1).

Nusa, A. S., \&Hariadi, B. 2015. Selling And Purchasing Internal Conrol Analysis At Forum Based E-Commerce (Case Study At Kaskus Market Forum). Jurnal Ilmiah Mahasiswa Feb, 3(1).

PT. Kereta Api Indonesia (Persero). 2014. Annual Report. Bandung.

2014.

Channel dan produke-commerce $\mathrm{PT}$ Kereta Api Indonesia (Persero). Web Page. (www.tiket.kereta-api.co.id, diakses 8 Januari 2016)

2014.

Company Profile. Bandung.

Santosa, S. 2004. Electronic Commerce: Tantangan Kompetensi Akuntan Dalam Menghadap iIsu Internal Kontrol. Jurnal Akuntansi Dan Keuangan, 4(1), Pp-36.

Virtania, ShieldsaWijono. 2013. Dampak E-Commerce Terhadap Pengendalian Internal Dan Proses Audit. Berkala Ilmiah Mahasiswa Akuntansi, 1(2), 96-100.

Wuryan, Andayani. 2008. Audit Intenal. Edisi 1. BPFE. Yogyakarta

Yin, Robert.K. 2009. Studi Kasus Desain \& Metode.Edisi Revisi. Jakarta :Rajawali Pers. 